Bangladesh J. Bot. 49(4): 1063-1069, 2020 (December)

\title{
SEED STORAGE PROTEIN ELECTROPHORETIC PROFILE AMONG POPULAR CULTIVARS OF DATE PALM (PHOENIX DACTYLIFERA L.)
}

\author{
Sadia Abdul Hayee, Sabeena Rizwan, Ashif SajJad ${ }^{1}$, Uzma Jabeen, \\ Farrukh Bashir, Ayesha Mushtaq*, Fareeda Behli, Shaista Anjum ${ }^{1}$, \\ TARIQ ISMAIL ${ }^{1}$ AND IRFAN HAFEEZ ${ }^{2}$ \\ Faculty of Basic Sciences, Sardar Bahadur Khan Women's University Quetta, \\ Quetta, Pakistan
}

Keywords: Seed storage, Popular cultivars, Date palm

\begin{abstract}
Evaluation of the seed storage protein electrophoretic profile among popular cultivars of date palm (Pheonix dactylifera) available in different regions of Balochistan, Pakistan was conducted. The genetic diversity of seed proteins of 12 cultivars were examined by electrophoresis. Twenty one protein bands with different mobility rates were identified within a molecular weight range of 11 to $351 \mathrm{KDa}$. The cultivar from Panjgur (Soorri) was well resolved on SDS-PAGE from the all other cultivars and gave the highest number of intense bands due to unique genetic build up. Genetic diversity among cultivars was evaluated by constructing the dendrogram for protein bands, which showed the cultivar (SP1) which is significantly different from all other cultivars on the basis of similarities in molecular weight of proteins.
\end{abstract}

\section{Introduction}

Date palm (Phoenix dactylifera L.) is the most traditional natural tree in the world. It is cited in holy books such as Quran and Bible (Barreveld 1993). Pakistan is rated among the largest producers of date-palm in the world. In Pakistan, Balochistan is the largest date-producing province. Popular varieties produced in the country are Aseel, Zahidi, Fasli, Maazwati, Dhakki, Kharbalian, Begum Jangi, Dagh, Goakna, Tota, Karwan, Hillavi, Khudrawi, and Mozawati Gulistan, Jowansur, Lango, Sabzo, Kharuba, Karbala, and Kupro (Sadeghi et al. 2014). Date palm is a pitted fruit and the chemical composition of date palm seed consists of approximately: ash $1.18 \%$, oil $10.36 \%$, protein content $5.67 \%$, total carbohydrate $72.59 \%$ and moisture $10.20 \%$. The major nutrients (mg/100 g of oil): potassium (255.43), magnesium (62.78), calcium (48.56) and phosphorus (41.33) (Nehdi et al. 2010). The mature seeds have storage protein is of great importance (Scott et al. 1992). Knowledge of genetic diversity is a useful tool in gene store management and planning experiments as it facilitates efficient sampling and utilization of germplasm. Seed protein patterns obtained by electrophoresis have been successfully used to resolve the taxonomic, evolutionary relationships among crops, their wild relatives, and determine genetic homology at the molecular level. They can also be used for distinguishing cultivars of particular crop species. SDS-PAGE is widely used due to its simplicity and effectiveness for describing the genetic structure of crop germplasm (Tanaka et al. 2000). The aim of the present study was to investigate differentiation among date palm cultivars of Balochistan by extraction, quantification, and characterization of seed storage proteins using SDS PAGE technique.

*Author for correspondence: <ayeshamushtaq2000@yahoo.com>. ${ }^{1}$ Faculty of Life Sciences, University of Balochistan, Quetta, Pakistan. ${ }^{2}$ PCSIR Laboratories Complex, Ferozepur Road, Lahore, Pakistan. 


\section{Materials and Methods}

Samples of the popular varieties (Panjgur, Kharan, Turbat and Sibi) of date palm were collected from different regions of Balochistan, Pakistan. Varieties collected from each region Soorri, Muzawati, Sabzo (from Panjgur), Rabbi, Sharifa, Dandara (from Kharan), Hossani, Muzaphati, Sore apandan (from Turbat) and Lashkari, Aseel, Karbala (from Sibi).

The seeds were ground into a fine powder and defatted by extraction with hexane and methanol using a Soxhlet apparatus. In the extraction method distilled water/acetone was used with minor changes (Murtaza et al. 2005). Date palm seed flour $(0.8 \mathrm{~g})$ was suspended in $12 \mathrm{ml}$ of reagent grade water. The suspension was agitated for $30 \mathrm{~min}$ in a shaker at room temperature and the suspension was centrifuged at $10,000 \mathrm{rpm}(12,000 \mathrm{~g})$ in a refrigerated centrifuge for $15 \mathrm{~min}$ at $10^{\circ} \mathrm{C}$. The supernatant was then filtered through No. 5A filter paper. The crude protein extract thus obtained. For SDS-PAGE analysis resolving gel (10\%) (3.8 $\mathrm{ml}$ tris-HCI buffer stock solution, $\mathrm{pH} 8.8,5 \mathrm{ml}$ acrylamide solution, $0.15 \mathrm{ml} \mathrm{10 \%}$ SDS, $6 \mathrm{ml}$ distilled water, APS $100 \mu \mathrm{l}$ TEMED 75 $\mu \mathrm{l})$ and Stacking Gel $(1.66 \mathrm{ml}$ tris-HCI stock solution, $\mathrm{pH}$ 6.8, $1 \mathrm{ml}$ acrylamide, $66 \mu \mathrm{l}$ of $10 \%$ SDS, $4 \mathrm{ml}$ of distilled water, APS $50 \mu \mathrm{l}$, TEMED $30 \mu \mathrm{l}$ ) were performed according to predefined method (Laemmli 1970). After electrophoresis, proteins were visualized with Coomassie Blue R250 .

\begin{tabular}{lc}
\hline Cultivar & Abbreviation \\
\hline Soori Panjgur & SP1 \\
Muzawati Panjgur & MP \\
Sabzo Panjgur & SP2 \\
Rabbi Kharan & RK \\
Sharifa Kharan & SK \\
Dandara Kharan & DK \\
Hossani Turbat & HT \\
Muzaphati Turbat & MT \\
Sore apandan Turbat & ST \\
Lashkari Sibi & LS \\
Aseel Sibi & AS \\
Karbala Sibi & KS \\
\hline
\end{tabular}

\section{Results and Discussion}

Extraction of fats from date palm seed was accomplished by the using a Soxhlet apparatus. Two dissimilar solvents used were $n$-hexane and methanol. Best results for defatted seed powder were obtained by the nonpolar solvent ( $n$-hexane) (Fig. 1). Because of the polar nature of methanol removal of oil was not possible. The results are in accordance with the data reported by Ali et al. (2015).

The protein was extracted from the defatted date palm seed powder according to method reported by Murtaza et al. (2005). This extraction procedure produced well resolved pattern of protein bands on SDS-PAGE in all extracted samples as compared to other extraction methods Akasha el al. (2012), Khoshroo et al. (2012). 
The quantification of date palm seed protein extract was done by Bradford method (Bradford 1976). The total content of seed protein in selected cultivars is presented in Table 1 . The results are in conformity with previously reported concentration of pulp protein determined by Khoshroo et al. (2013).

To obtain reproducible and good protein separation acrylamide gel concentrations such as $10 \%$ were used. By using software GelAnalyzer 2010a the molecular mass of different crude proteins was calculated with reference to the molecular mass of protein marker. The date palm seeds storage proteins band with molecular weight running from 20 - $351 \mathrm{kDa}$ were named P1 to P21 (Fig. 2). Heavily stained bands were observed in four (4) cultivars MT, DK, AS, SP1. The highest 14 resolving bands were obtained by the cultivar SP1 (Soorri Panjgur) while KS (Karbala Sibi) and LS (Lashkari Sibi) had lowest bands as compared to the other cultivars. The comparison of protein profiles amongst 12 varieties illustrated that they share 11 same molecular weight protein bands. Alternate bands, p15 were just present in (MT, ST, HT, SK), P3 in (MT, DK, AS, MP, SP1, SP2, RK), P2 in (MP, SP1, SP2) and P1 just in SP1. More plenteous bands are P4, P6 and P7.

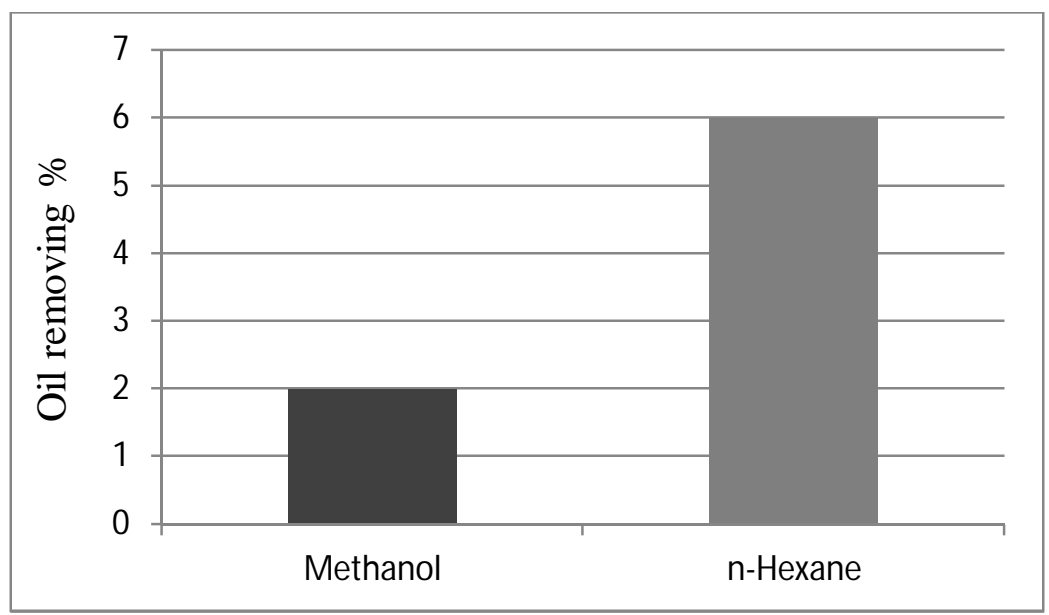

Fig. 1. Effect of solvent type on oil removing.

Table 1. Protein content of varieties.

\begin{tabular}{lcccccccccccc}
\hline Varieties & SPI & SP2 & MP & MT & ST & HT & DK & RK & SK & KS & AS & LS \\
\hline $\begin{array}{l}\text { Protein content } \\
\mathrm{mg} / \mathrm{ml}\end{array}$ & 2.13 & 1.84 & 1.97 & 1.98 & 1.86 & 1.88 & 1.95 & 1.89 & 1.89 & 1.85 & 1.90 & 1.80 \\
\hline
\end{tabular}

Significant bands were observed with various molecular weights for the date seed storage proteins. The most intense band having molecular masses of approximately 75, 73 and $68 \mathrm{kDa}$ were observed in all cultivars. The protein bands almost found in all cultivars with small molecular mass were detected at $20 \mathrm{kDa}$ could be alcohol dehydrogense and at $21 \mathrm{kDa}$ could be calmodulin related protein. The observation of protein bands with molecular weight $27,29 \mathrm{kDa}$ is in accordance with the reports by Bevan et al. (1998) they could be triosephosphate isomerse, and 40s ribosomal protein, respectively. The bands from $35-47$ could be seed maturation protein. 
Protein bands with molecular weights 48, 49, 51 and $62 \mathrm{kDa}$ could be enolase, LEA protein, Atp B and calnexin homolog, respectively, observed in all cultivar approximately. Higher molecular weight, and less intense protein band of $351 \mathrm{kDa}$ were only observed in cultivar SP1 and 97 (lipoxygense), 94 (eukaryotic translation elongation factor) $\mathrm{kDa}$ were observed in cultivars MT, DK, AS, MP, SP1, SP2 and RK variety, which were not identified. In additional varieties of date palm seed results are in agreement with the study of Akasha et al. (2016). Khoshroo et al. (2012) have reported similar results based on an analysis of seed protein from 12 varieties of date palm

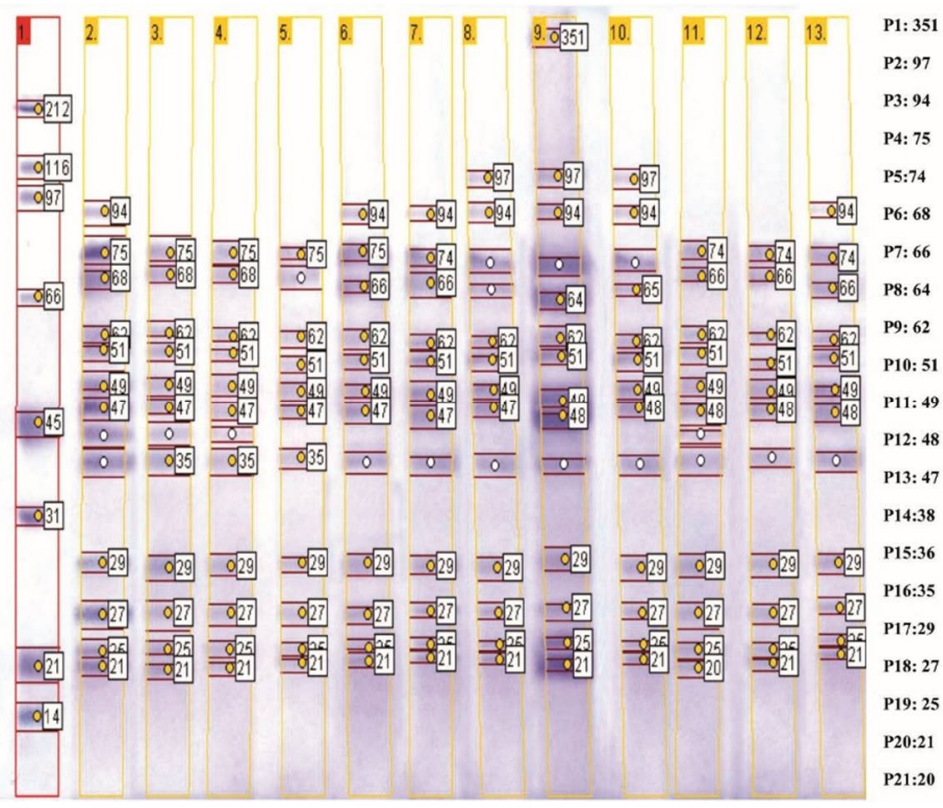

Fig. 2. SDS-PAGE of date palm seed protein profiling.

Table 2. The protein bands revealed by the analysis are lumped into 3 groups of molecular weights including the number of bands for every cultivar.

\begin{tabular}{lllllllllllll}
\hline Varieties & MT & ST & HT & KS & DK & AS & MP & SPI & SP2 & SK & LS & RK \\
\hline $\begin{array}{l}\text { A } \\
(14-30)\end{array}$ & 4 & 4 & 4 & 4 & 4 & 4 & 4 & 4 & 4 & 4 & 4 & 4 \\
$\begin{array}{l}\text { B } \\
(30-65)\end{array}$ & 6 & 6 & 6 & 5 & 5 & 5 & 5 & 5 & 5 & 5 & 6 & 5 \\
$\begin{array}{l}\text { C } \\
(65-31)\end{array}$ & 3 & 2 & 2 & 2 & 3 & 3 & 4 & 5 & 4 & 2 & 2 & 3 \\
$\begin{array}{l}\text { Total } \\
\text { bands }\end{array}$ & 13 & 12 & 12 & 11 & 12 & 12 & 13 & 14 & 13 & 12 & 11 & 12 \\
\hline
\end{tabular}

grown in different Iranian regions. They found one heavily stained band at around $65 \mathrm{kDa}$ and minor bands ranging from $12 \mathrm{t}-369 \mathrm{kDa}$. Bouaziz et al. (2008) found three similar prominent protein bands in date seeds of Allig and Deglet Nour varieties at 32, 60 and $70 \mathrm{kDa}$. The differences in protein profile between present results and the previous works (Bouaziz et al. 2008, 
Koshroo et al. 2012) could be explained by a number of factors. The extraction process used by the other workers differs from present one and this might lead to differential extraction of proteins. Variation between the seed storage proteins is expected within different varieties of the same species. This genetic polymorphism may occur through the presence of multigene families within the same species, or through post-translational glycoslylation of proteins, or proteolytic action on the proteins (Miernyk and Hajduch 2011). The finding in the present study was found to be consistent with previous reports for recalcitrant plant tissues (Lee et al. 2017). The hereditary diversity of cultivars was considerable among 12 cultivars (Table 2). For the helpful description, all bands were arranged into three parts assigned as a (14-30 MW), b (30-65 MW) and c (65$350 \mathrm{MW})$. Region a (14-30 kDa) in this region all the cultivars have the same number of bands. Region b (30-65kDa) in this region MT, ST, HT, and SK have 6 bands while other has 5 bands. Region c $(65-351 \mathrm{kDa})$ in this region number of bands varied in all the cultivars. The highest 14 resolving bands were obtained by cultivar SP1 while KS and LS cultivars have the lowest number of bands as compared to other cultivars. The presence or absence of protein bands has also been applied for detection of polymorphism of Brassica cultivars (Khurshid et al. 2012).

The genetic similarity based on the Jaccard's method on the basis of presence and absence of bands. Cluster analysis of seed storage proteins was performed on the results of SDS-PAGE using UPGMA. In this study the protein pattern heterogeneity between 12 cultivars of Phoenix dactylifera L. was compared by four clusters. Fig. 3 shows a dendogram based on the electrophoretic profile of total crude protein extracted from seed of selected date cultivars. The horizontal axis of dendrogram represents the distance or dissimilarity between samples. A vertical axis represents the object and clusters. Dendrogram shows that cultivars ST and HT are more similar to SK. DK and AS were close to RK and MP. Similarly KS and LS then SP2. SP1 was substantially different from all of the other cultivars.

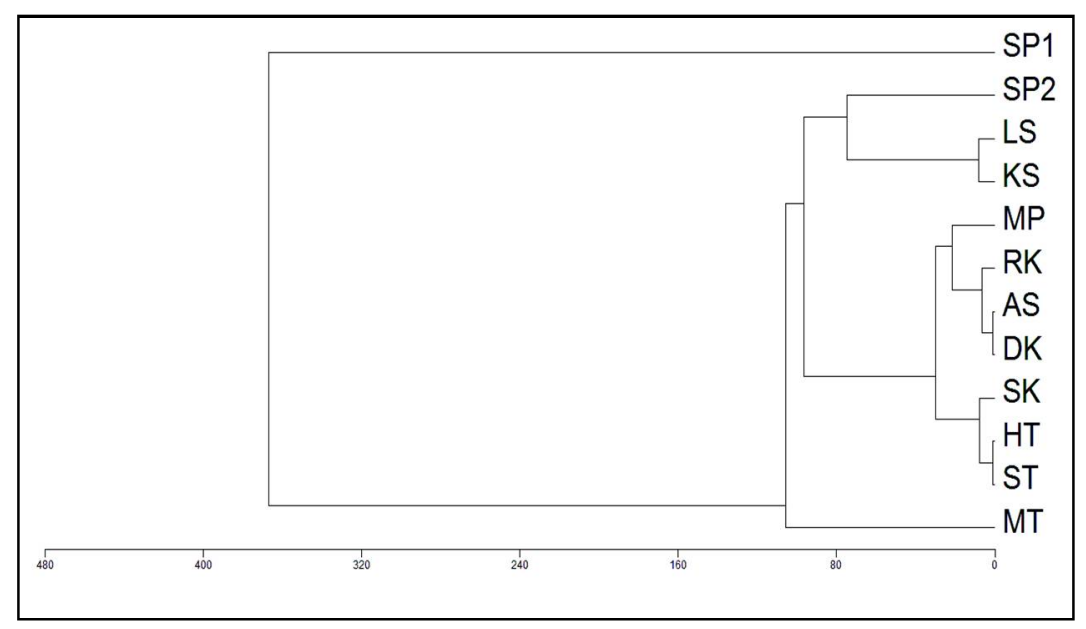

Fig. 3. Dendrogram showing the genetic relationship between the cultivars.

Cultivars included in the present study were referred to one genetic origin. Such conclusions were reported in other local cultivars (Mohammad et al. 2015), and agree with the conclusions, that the diversity of protein bands between the varieties within the species are generally low (AlKhalifah et al. 2012). It is agreed that 12 cultivars utilized as a part of this examination were practically similar to each other; despite expected, the SP1 cultivar from Panjgur showed striking 
hereditary polymorphism. This investigation likewise gave data about the genotype of date palm as the recognizable proof of three wheat genotypes. The result of differentiation agreed with yellow sarson and brown seeded types of Brassica clearly separated the yellow seeded and brown seeded varieties by SDS PAGE accounted by Das et al. (1995).

\section{References}

Ali MA, Al-Hattab, TA and Al-Hydary IA 2015. Extraction of date palm seed oil (Phoenix dactylifera) by Soxhlet apparatus. Int. J. Adv. in Eng. Technol. 8(3): 261.

Al-Khalifah, NS, Askari E and Khan AS 2012. Molecular and morphological identification of some elite varieties of date-palms grown in Saudi Arabia. Emirates J. of Food \& Agri. 24(5): 456-461.

Akasha I, Campbell L, Lonchamp J and Euston SR 2012. Extraction and characterization of protein fraction from date palm fruit seeds. World Acad. Sci. Eng. Technol. 70: 292-294.

Akasha I, Campbell L, Lonchamp J and Euston SR 2016. The major protein of seed of fruit of date palm Pheonix dactylifera L. Characterization and emulsyfying properties. Food Chem. 197(2): 799-806.

Barreveld WH 1993. Date palm products. Agricultural services bulletin no. 101. FAO, Rome.

Bevan M, Bancroft I, Bent E, Love K, Goodman H, Dean C, Stiekema W 1998. Analysis of $1.9 \mathrm{Mb}$ of contiguous sequence from chromosome 4 of Arabidopsis thaliana. Nature 391: 485-488.

Bouaziz MA, Besbes S, Blecker C, Wathelet B, Deroanne C and Attia H 2008. Protein and amino acid profiles of Tunisian DegletNour and Allig date palm fruit seeds. Fruits 63(1): 37-43.

Bradford MM 1976. A rapid and sensitive method for the quantitation of microgram quantities of protein utilizing the principle of protein-dye binding. Anal. Biochem. 72(1-2): 248-254.

Das S and Mukherjee K 1995. Comparative study on seed proteins of Ipomoea. Seed Sci. Technol. 23(2): 501-509.

DeMason DA, Sexton R and Reid JSG 1983. Structure, composition and physiological state of the endosperm of Phoenix dactylifera L. Annals of Bot. 52: 71-80.

Khurshid H and Rabbani MA 2012. Comparison of electrophoretic protein profiles from seed of different oilseed Brassica cultivars. J. Pub. Health Biol. Sci. 1(2): 36-42.

Khoshroo MR, Baghizadeh A and Homayounfar F 2013. Characterization of seed storage proteins in some Iranian date palm cultivars using SDS-PAGE. Anale le Stiintifice ale Universitatii. Geneticasi Biologie Moleculara 14(2): 1.

Khoshroo SMR, Khavarinejad R, Baghizadeh A, Fahimi H and Mohammadi ZN 2012. Seed storage protein electrophoretic profiles in some Iranian date palm (Phoenix dactylifera L.) cultivars. Afr. J. Biotechnol. 10(77): 17793-17804.

Laemmli UK 1970. Cleavage of structural proteins during the assembly of the head of bacteriophage T4. Nature 227(5259): 680-685.

Lee HX, Ahmad F, Saad B and Ismail MN 2017. Evaluation of extraction methods for the identification of proteins from date palm (Phoenix dactylifera L.) seed and flesh. Preparative Biochem \& Biotech. 47(10): 998-1007.

Meier H 1956. On the submicroscopic structure of mannans. Proc. Stockholm Conf. of Electron Microsc. 289-300.

Miernyk JA and Hajduch M 2011. Seed proteomics. J. Proteomics 74(4): 389-40.

Mohammad AA 2015. Electrophoretic analysis of proteins from different date palm (Phoenix dactylifera $\mathrm{L}$.) cultivars in Saudi Arabia. Afr. J. Biotech. 14(15):1325-1333.

Murtaza N, Qayyum A and Khan MA 2005. Comparative study of the soluble storage proteins in Gossypium hirsutum L. germplasm through Electrophoresis. Int. J. Agric. Biol. 7(2): 253-256.

Nehdi I, Omri S, Khalil, MI. and Al-Resayes SI 2010. Characteristics and chemical composition of date palm (Phoenix canariensis) seeds and seed oil. Industrial Crops and Products 32(3): 360-365.

Sadeghi Z and Kuhestani K 2014. Ethnobotany of date palm (Phoenix dactylifera) in Baluch tribe of Saravan region, Baluchistan, Iran. J. Agric. Technol. 10(6): 1571-1585. 
Scott MP, Jung R, Muntz K and Nielsen NC 1992. A protease responsible for post-translational cleavage of a conserved Asn-Gly linkage in glycinin, the major seed storage protein of soybean. Proc. Natl. Acad. Sci. 89(2): 658-662.

Tanaka T and Matsunaga T 2000. Fully automated chemiluminescence immunoassay of insulin using antibody-protein A-bacterial magnetic particle complexes. Anal. Chem. 72(15): 3518-3522.

(Manuscript received on 17 February, 2020; revised on 5 April, 2020) 